\title{
Moses, happy man?
}

\author{
Darrin M. McMahon
}

\begin{abstract}
This article exams the Biblical figure Moses in the light of both ancient and modern understandings of happiness, asking whether Moses himself was happy, and what that might mean, and whether he may be considered an example of a "felicitator," one who works successfully for the happiness of others.
\end{abstract}

Keywords: religion, Jewish happiness, blessedness, felicitator

From the perspective of the twenty-first century, Moses may seem an odd choice to serve as a model purveyor of human happiness. True, he is said to have accomplished a series of no mean feats-leading an entire people out of bondage to the brink of the Promised Land, communicating directly with God, and receiving God's law, which has provided untold millions with the resources to live lives of sanctity and peace. He even parted the Red Sea! That said, some will question whether he ever lived. And even those who cede his existence may be excused if they come away from a cursory reading of the Pentateuch - the first five books of the Jewish Bible/Christian Old Testament and our principal source of information about the manwith a less than cheery view of his life and times. After all, Moses served as the perpetrator and agent of terrible violence and destruction, divinely conferred on the enemies of Israel and those unfortunate enough to have crossed Yahweh's path. An orphan, whose parents were forced to abandon him as an infant, Moses was relatively fortunate in adoption, allowed to run the halls of Pharaoh. And yet one need not be a psychologist to wonder just how well things turned out. For clearly Moses was a man of hot temper, prone to rash outbursts and acts of violence. He committed murder as a young adult, provoked by the sight of injustice (Exodus 2:12), later smashing up tablets and giving himself over to acts of rage and destruction when his "anger burned hot" (Exodus 32:19), incensed, as he very often was, by the failings of others. ${ }^{1}$ Awkward in social situations, "slow of speech and slow of tongue" (Exodus 4:10), Moses seems to have possessed very little of those qualities of extroversion and volubility that psychologists today tend to associate with positive emotion. When examined as a whole, his life would seem rather bleak-tragic even-filled with privation, annoyance, and ultimate failure, a life spent wandering in a wilderness, bearing the constant complaints and ingratitude of those around him. If his great life's goal was to set foot in the Promised Land, and deliver his people to freedom, then his life must be deemed a failure. "You shall not enter there," the Lord tells Moses (Deuteronomy, 1:37), judging that he, with his brother Aaron, had broken faith "by failing to maintain my holiness among the Israelites" (Deuteronomy 32: 51). And though it is the case that God permits him a glance across the River Jordan, revealing that Moses' people will enter the land of milk and honey in his place, he cannot take much solace in the thought.

${ }^{1}$ All Biblical references are drawn from the New Revised Standard Version. 
For Moses is also told that his descendants will prove unworthy of their deliverance, and shall fall quickly again into bondage and despair. As God reveals:

Soon you will lie down with your ancestors: Then this people will begin to prostitute themselves to the foreign gods in their midst, the gods of the land into which they are going; they will forsake me; breaking my covenant that I have made with them. My anger will be kindled against them in that day. I will forsake them and hide my face from them; they will become easy prey, and many terrible troubles will come upon them. (Deuteronomy 31:16)

A life of struggle and sacrifice has apparently ended in vain. Surely, to call Moses 'happy' is a stretch. Wouldn't it be truer, modern readers may well wonder, to say that Moses made himself miserable, and many others besides?

They would hardly be the first to entertain the thought. From at least the time of the European Enlightenment, many have said as much, and more, concurring with Voltaire, who was content to write off the entire story of Moses as so much fanaticism and superstition. "It is very pardonable," he observes in his article "Moses" in the Philosophical Dictionary, "to see in such a history the barbarous stupidity of the first ages of a savage people...." ${ }^{2}$ Not only were many of Voltaire's contemporaries skeptical of the veracity of the Biblical account, but the more radical among them were inclined to associate religion itself with a good deal of gratuitous suffering and unhappiness. A century and a half later an admirer of Voltaire, Sigmund Freud, essentially agreed, suggesting in his final work that not only was the Biblical account of Moses' life a pious fiction, but that Moses was in fact not a Jew. ${ }^{3}$ An Egyptian nobleman (and in Freud's opinion an enlightened one at that), Moses was murdered by his Israelite followers, who later felt deep regret at their primal act of aggression. The upshot was that Moses had bequeathed to the Jewish people an indelible sense of guilt for which they continued to seek atonement, and forever in vain. In Freud's opinion-not unlike that of the Radical Enlightenment and very much like that of today's so-called 'New Atheists' (whose arguments have been around for several hundred years) - religious belief was not just false, it made us miserable as well.

To be sure, many have disagreed with this assessment over the centuries, not least practising Jews, Christians, and Muslims, all of whom venerate Moses to this day as a paragon and prophet. From relatively early on in the Jewish tradition, moreover, there was an attempt to present Moses not simply as a prophet of the Jews - a man specially chosen to lead the tribes of Israel to deliverance-but an ideal human being of universal stature. The philosopher Philo of Alexandria, for example, writing in Greek to a cultivated Hellenistic audience in the early first century, drew on the Midrash as well as classical learning to present Moses as "the greatest and most perfect man that ever lived." "Similarly, the historian Josephus, Philo's rough contemporary, took pains to represent Moses as an archetypal man, who embodied the cardinal classical virtues of courage, wisdom, temperance, and justice, and who combined in his person the attributes of Pericles, Aeneas, the stoic sage, and Plato's philosopher king. It may be questioned how many pagans accepted this portrait in the late Antique world, and yet Christians for their part enthusiastically embraced the image of Moses as a universal man.

\footnotetext{
${ }^{2}$ Voltaire, "Moses," (Philosophical Dictionary) in The Works of Voltaire. A Contemporary Version. A Critique and Biography by John Morley, notes by Tobias Smollett, trans. William F. Fleming, 21 vols. (New York: E.R. DuMont, 1901), 6:41.

${ }^{3}$ Sigmund Freud, Der Mann Moses und die monotheistische Religion (1939).

${ }^{4}$ Cited in Louis H. Feldman, Philo's Portrayal of Moses in the Context of Ancient Judaism (South Bend, Indiana: University of Notre Dame Press, 2007), 3.
} 
Indeed, in a sort of Judeo-Christian version of Classical parallel lives, they embraced Moses as the predecessor and prefiguration of Jesus (Joshua) himself. Had not Moses declared in Deuteronomy 18.15 that "The Lord your God will raise up for you a prophet like me from among your own people," and that "you shall heed such a prophet"? Reading scripture in reverse, Christians hailed Jesus as that very same man. In doing so, they anointed Moses as the 'first savior' whose work was to be completed by the 'new Moses,' the Messiah Christ. Muslims, for their part, would later draw attention to this same passage in Deuteronomy to bolster their claim, asserted frequently in the Qur'an, that Moses was a "messenger of Allah," and one of the greatest men who had ever lived. With the exception of Mohamed, who in the Islamic understanding is the chosen one who completes Allah's work, Moses is mentioned in the Qur' an more than any other prophet. With reason is he revered as a human being "specially chosen" (Qur'an 19: 51-53). For the followers of all three of these traditions, then-Jews, Christians, and Muslims - there can be no doubt that Moses was a man apart, a paragon of human excellence and immense moral stature.

But can we conclude from this that Moses was deemed 'happy' in the eyes of his beholders? Do believers, in other words, consider Moses a happy man? And what might that conviction say to those who refuse to look at him solely through the lens of faith? Is there any basis for considering Moses 'happy' from the standpoint of contemporary science? And finally how might we judge whether he was in truth a 'felicitator' enabling others to live happier lives?

The answers to all these questions depend, in large part, on what we mean by the term, and here it might be useful to insist on how widely the meaning of the word has varied through the ages. ${ }^{5}$ It is certainly true, as the psychologist Paul Ekman has famously shown, that all peoples in all places smile to signify joy and delight, just as they share other universal expressions to indicate fear, disgust, anger, surprise, and sadness. ${ }^{6}$ But it hardly follows that all cultures and peoples think of happiness in the same way. On the contrary, both across space and across time, men and women have come to very different conclusions about what constitutes happiness and who might be deemed to lead a happy life.

The word that classical Hebrew employed to signify the state of happiness is Asher (אָשָָ), and though it is always perilous to venture etymologies of such ancient terms, lexicographers point to a connection with the root 'sr, meaning "to go," "to go straight," or "to advance."7 That would explain why variants of the term are used synonymously with the noun "step," as in Psalm 17:5, where we read that "My steps have held fast to your path; my feet have not slipped," so rendering the Hebrew beatitude found at the beginning of Psalm 119 of particular interest. "Happy (asher) are those whose way is blameless, who walk in the way of the Lord." In this case the first step to happiness was the step itself, a connection that would certainly have

\footnotetext{
${ }^{5}$ For an insightful rumination on precisely this question in the context of the Torah and ancient Greek philosophy, see Nathan MacDonald, "What has Athens to do with Jerusalem? Is There Happiness in the Torah?," in Brent A. Strawn, ed., The Bible and the Pursuit of Happiness (New York: Oxford University Press, 2012). I am grateful to Professor MacDonald for kindly sharing this article with me prior to its publication, and also for generously reading, with the eyes of a professional Old Testament scholar, a draft of the present piece, written by an (interested) amateur.

${ }^{6}$ For a concise, early statement of the position he has developed throughout his long and distinguished career, see Paul Ekman, “Universal Facial Expressions of Emotion," California Health Research Digest 8, no. 4 (Autumn, 1970), 151-58.

7 The account here draws on the discussion in my Happiness: A History (New York: Atlantic Monthly Press, 2006), 7781. For ancient Jewish understandings of happiness more generally, see the rich account provided in Hava TiroshSamuelson's Happiness in Premodern Judaism: Virtue, Knowledge, and Well-Being (Cincinatti: Hebrew Union College Press, 2003), as well as Gary A. Anderson, A Time to Mourn, a Time to Dance: The Expression of Grief and Joy in Israelite Religion (University Park, PA: Pennsylvnia University Press, 1991).
} 
resonated with Moses' followers, who were engaged, after all, in marching from the misery of bondage to the milk and honey of freedom. By putting one foot in front of the other, they undoubtedly hoped, they would make their way to happiness on the horizon, the Promised Land of milk and honey, a place of peace and rest and abundance, a land of fertile soil.

Happiness, in this connection, was an earthy affair. It was in other respects as well. For asher is not only derived from the root 'sr, it is the name of one of Israel's twelve tribes. The brother of Gad and the second son of Zilpah, Leah's maid, who was made pregnant by Jacob when his wife was past child-bearing years, Asher earned his name from Leah's exclamation upon his birth. "'Happy am I! For the women will call me happy,' so she named him Asher" (Genesis 30.12-13). Here happiness is associated, as it is in so many ancient cultures, with good fortune, fecundity, and bounty, a connection that is echoed by Moses himself when he blesses Asher in Deuteronomy 33.24: "And of Asher he said: Most blessed of sons be Asher; may he be the favorite of his brother, and may he dip his foot on oil." Oil, here, the oil of olives, crushed by foot like grapes, was a symbol of prosperity, and so Moses wishes Asher's tribe, Israel's largest, continued fertility and abundance. His blessing, in this respect, partakes of a more comprehensive vision of what earthly happiness might entail. It is, to repeat, an earthy vision, one entirely appropriate to a people close to the land-shepherds and farmers - whose lives and fortunes are precarious. To those threatened continually by war, famine, dearth, and disease, there could be nothing more pleasing than a vision of safety and bounty, teaming families, and ripe old age. We get a similar glimpse of Asher's blessing, and the blessing of what it meant to be asher in Psalm 128:

Happy is everyone who fears the Lord, who walks in his ways.

You shall eat the fruit of the labor of your hands;

you shall be happy, and it shall go well with you.

Your wife will be like a fruitful vine within your house;

your children will be like olive shoots around your table

Thus shall the man be blessed who fears the Lord.

The Lord bless you from Zion.

May you see the prosperity of Jerusalem

all the days of your life.

May you see your children's children.

Peace be upon Israel!

But all of this, it should be stressed - the fruits of one's labor, peace of mind and person, longevity and health, fecundity of table and bed-is made contingent on keeping God's laws and God's favor, walking (stepping) in his ways. The happiness of Asher may be earthy, but it is also spiritual, predicated on divine blessing. It is revealing in this connection that Moses, when

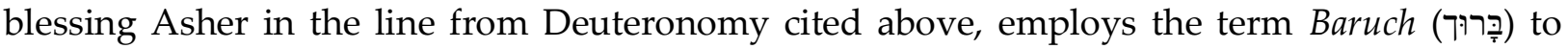
describe him as "most blessed." 8 The word, a term of praise when applied to God, indicates,

${ }^{8}$ On the word 'Baruch,' see Christopher W. Mitchell, The Meaning of BRK "To Bless" in the Old Testament (Atlanta: Scholar's Press, 1983). 
like asher, a state of happiness when applied to human beings, though with a stronger spiritual connotation. And while any Jew, like any reader of the Hebrew Bible, need only consider the fate of Job (to say nothing of Jewish history) to know that keeping God's laws is no guarantee of prosperity and good fortune, it is an indispensable precondition nonetheless, one that comes with an implicit promise, which carries with it hope, the hope that the blessing of happiness will be conferred on those who merit God's favor. By walking in God's way, one sets a course for the Promised Land: The road to happiness is paved by God's commands.

Moses, then, opened up an avenue to the good life, one that stressed happiness as a process and pattern of living, an activity and movement, in which the journey itself was as important as the arrival. God's law, in short, as revealed by Moses, was a regime for human flourishing. ${ }^{9}$ Seen from the outside, to be sure, and in the light of the twenty-first century, certain stipulations may seem peculiar, if not downright odd, as they did already to various early Christians and Pagans like Origen and Celsus, or to even more perplexed critical enquirers at the time of the European Enlightenment, who balked, after two centuries of religiously inspired bloodshed, at the injunction, say, that "You shall not permit a female sorcerer to live" (Exodus 22:18). Similarly, we may be inclined to ask now why "No one whose testicles are crushed or whose penis is cut off [should] be admitted to the assembly of the Lord" (Deuteronomy 23.1). And what harm can it do, we might legitimately wonder, to "wear clothes made of wool and linen woven together" (Deuteronomy 22.11)? Biblical scholars and anthropologists possess answers to such questions, though in the end the particulars of the law are for rabbis and priests to interpret, and for the faithful to live as they best see fit. And yet all but the most uncharitable observer should be able to acknowledge that to focus exclusively on provisions of this kind is to blind oneself to much that is not only deeply familiar in the Pentateuch - the Mosaic law, after all, beginning with the Decalogue, is part and parcel of the Western ethical and legal tradition-but also, from the perspective of happiness, much of what has been confirmed by centuries of reflection and, more recently, by mountains of research. To those who have taken the trouble to familiarize themselves with the literature on the modern science of happiness, for example, a good deal of what Moses has to say will come across as strikingly astute, a fine illustration of what the psychologist Jonathan Haidt has described as "modern truth in ancient wisdom." ${ }^{\prime 10}$

Take, for example, the issue of gratitude. Contemporary psychologists and philosophers of emotion stress that, although the relationship between gratitude and happiness is undoubtedly complicated, there are nevertheless numerous ways in which gratitude "enhances or protects happiness and well-being" when consciously cultivated as a virtue. ${ }^{11}$ To feel and express gratitude is to call to mind the good others have done us, which is almost always a spur to positive emotion. Similarly, to forgive is to free ourselves from thoughts and resentments that may cause us pain, urging us to let go of the harm others have done us. The Hebrew Bible is nothing if not a primer in the expression of gratitude and forgiveness. Regarding the latter, it is Moses who urges the Lord to forgive his people when they forge an idol in the image of a Golden Calf, and it is Moses who continually implores, as he does right before the forging of

\footnotetext{
${ }^{9}$ On this point, see Tirosh-Samuelson, Happiness in Premodern Judaism, $316 \mathrm{ff}$, as well as Norma Roth, "Attaining Happiness (Eudaimonia) in Medieval Jewish Philosophy," Centerpoint 4 (1981), 21-32 and Erwin I. J. Rosenthal, "The Concept of 'Eudaimonia' in Medieval Islamic and Jewish Philosophy" in his Studia Semitica, 2 vols. (Cambridge: Cambridge University Press, 1971), 2:127-44.

${ }^{10}$ Jonathan Haidt, The Happiness Hypothesis: Finding Modern Truth in Ancient Wisdom (New York: Basic Books, 2006). Though Haidt only discusses Moses and Judaism in passing, he would, I think, accept the comparison.

${ }^{11}$ See, for example, Robert C. Roberts, "Gratitude: A Conceptual Analysis," in Robert A. Emmons and Michael E. McCullough, eds., The Psychology of Gratitude (New York: Oxford University Press, 2004), 77.
} 
the covenant, that "Although this is a stiff-necked people, forgive our wickedness and our sin" (Exodus 34.9). Moses himself repeatedly forgives the people he leads, who are forever prone to wander, err, and disappoint. In so far as his own conduct can be taken as a model for others, he instructs by example, just as he inculcates the virtue of gratitude. The central sacrificial rite spelled out to Moses in Deuteronomy 26, for instance, whereby those "who have come in to the land that the Lord your God is giving you as an inheritance," shall deliver the "first fruits" of the fields in calling to mind his mercy, benevolence and kindness in delivering them from Egypt is, in effect, a call to the performance of ritual gratitude, a reminder to celebrate one's blessing and rejoice. The so-called "thank-offering" or "fellowship offering" detailed in Leviticus 7:11-13 serves a similar function, instructing individuals how to offer a personal "expression of thankfulness" to God for his beneficence. And finally, the Passover Seder, celebrated to this day as a feast of joyful remembrance and thanksgiving, bids all those gathered at table to recall with gratitude the narrative so vividly recounted in the PentateuchGod's liberating power in Egypt, and his guidance, then as now, to Jerusalem.

It bears emphasis that Moses' promptings to gratitude and forgiveness are ultimately intended, like the deliverance from Egypt itself, as collective endeavors. We ought, of course, to be grateful and to forgive as individuals in our personal relationship to God, but in the final analysis it is in the context of community that such injunctions make sense. We could say the same about Moses' teaching as a whole, and about the understanding of happiness that emerges from them, for the law and the exodus and arrival in the Promised Land are projects of an entire people. The happiness of each is contingent in part on the happiness of all, and so to keep God's laws, to walk in his way, to know prosperity, peace, fecundity, bounty and familial love is to do so in a resolutely social environment. No man is an island, and there are no islands in the desert.

That insight is one that modern researchers on happiness would wholeheartedly confirm, attesting, as they frequently do, to the fundamentally social nature of happiness, which is sustained by rich networks of friendship and mutual support. Moses is the leader of a people and it is to a people that he reveals God's law, leading them collectively on the road to Jerusalem. The vision of hope that he provides is one of collective deliverance, and, in the end, that is probably Moses' greatest bequest, providing not just the hope of happiness, but the happiness of hope. For it is that very narrative-that human beings, acting in concert, can take steps together toward their own transformation, sustaining themselves in the process by a vision of the happiness on the horizon - that has moved so many millions over the centuries. ${ }^{12}$ It is a powerful narrative, the movement from bondage to freedom, and a powerful vision, the milk and honey of the Promised Land, all the more inspiring in that it bids us to action and engagement. The Exodus narrative may be a chronicle of God's intervention in history, but it is also an account of human agency, of human beings taking action and making progress in the pursuit of their own destination and deliverance. It is, in this respect, not just an inspiring tale, but an empowering one, suggesting that human beings can do something about their own happiness. We can take steps towards our destination and deliverance. And though the road may be difficult, full of challenges and setbacks, there is hope on the horizon.

Lest that sound like a mere rhetorical flourish, consider how many millions of men and women, Jew and gentile alike, have been moved by that vision, and are still moved to this day. Hope, modern researchers affirm, is a source of resilience, optimism, and happiness itself. It has

${ }^{12}$ See Michael Walzer's classic Exodus and Revolution (New York: Basic Books, 1985). 
put energy into countless steps. ${ }^{13}$ The example of Moses and the narrative of the movement from bondage to slavery gave conviction to radicals who fought against absolute monarchs in seventeenth-century England, and who defied King George in eighteenth-century America. Thus the Reverend Thomas Coleman, preaching before Parliament on August 30, 1643, likened his countrymen's struggle against King Charles, typically, to the ancient Israelites' "long pursuit of happinesse."14 And in the New World at the time of the American Revolution, the example of Moses was so prevalent (and comparisons to King George III as pharaoh so common) that when the Continental Congress asked a committee to design a seal for the newly proclaimed United States immediately following the Declaration of Independence, two of its members, Benjamin Franklin and Thomas Jefferson, proposed an image of the Biblical leader leading the Israelites to freedom. ${ }^{15}$ More recently, the exodus narrative helped the followers of Martin Luther King to brave water cannons and snarling dogs in their own march to the Promised Land. Jerusalem may lie, both temporally and spatially, on the horizon: We will arrive there 'next year.' But the journey itself is better for the thought of the arrival.

Was Moses, then, a happy man? In our contemporary language-with its connotation of smiling faces and ready good cheer-almost certainly not. But in the terms of his own time the description is more likely. Notwithstanding his many privations and discomforts, Moses married, had two sons (even if we hear almost nothing about them), and lived to the ripe old age of 120 (Deuteronomy 34:7). His life, to be sure, was never one of pastoral peace and bounty, and was often plagued by anger and dissatisfaction. But what rendered Moses both asher and baruch in the eyes of his contemporaries was not domestic comfort and the fruits of the earth, but rather his uniquely privileged relationship to God. He was a man "whom the Lord knew face to face" (Deuteronomy 34:12), singularly blessed by him. And though that special relationship presented, like life itself, severe challenges and setbacks, it enabled Moses to set a great many human beings in motion.

And that, from the perspective of the papers collected in this volume, is ultimately Moses' greatest achievement, what renders him worthy of the label we are using here. Moses was a felicitator not insofar as he himself was (or was not) a model of a happy man. Nor is he one who may be said to have brought smiles regularly to the faces of others. Rather, like all great leaders whose anger burns hot at the sight of injustice, he struggled continually to free others from the constraints that bound them. In so doing, he bequeathed a gift that in the end may be even greater than happiness - the freedom to strive for it ourselves, and the prospect that it lies within our power to attain this coveted end.

\section{Author}

Darrin M. McMahon

Florida State University

dmcmahon@fsu.edu

\footnotetext{
13 There is, now, an extensive literature on the relationship between happiness, hope, and optimism. An essential starting place is Martin Seligman's seminal Learned Optimism (New York: Knopf, 1991).

14 Thomas Coleman, The Christian's Course and Complaint, Both in the Pursuit of Happinesse Desired, and for Advantages Slipped in that Pursuit: A Sermon Preached to the Honorable House of Commons on the Monthly Fast day, August 30, 1643 (London: I.L., 1643), 8.

${ }^{15}$ Although the proposed seal was not adopted in the end, the invocation of the Exodus narrative in Revolutionary America was extensive, with George Washington frequently cast as "the American Moses." See Todd Gitlin and Liel Leibovitz, The Chosen Peoples: America, Israel, and the Ordeals of Divine Election (New York: Simon and Schuster, 2010), esp. 66-7.
} 


\section{Publishing Timeline}

Received 31 January 2011

Accepted 16 March 2011

Published 20 July 2011

\section{References}

Coleman, T. (1643). The Christian's course and complaint, both in the pursuit of happinesse desired, and for advantages slipped in that pursuit: A sermon preached to the honorable House of Commons on the monthly fast day, August 30, 1643. London: I.L., 8.

Ekman, P. (1970). “Universal Facial Expressions of Emotion,” California Health Research Digest 8, no. 4, 151-58.

Feldman, L. H. (2007). Philo's portrayal of Moses in the context of ancient Judaism. South Bend, IN: University of Notre Dame Press, 3.

Freud, S. (1939) Der Mann Moses und die monotheistische Religion. Amsterdam: Verlag Allert de Lange.

Gitlin, T. \& Leibovitz, L. (2010). The chosen peoples: America, Israel, and the ordeals of divine election. New York, NY: Simon and Schuster.

Haidt, J. (2006). The happiness hypothesis: Finding modern truth in ancient wisdom. New York, NY: Basic Books.

MacDonald, N. (forthcoming). What has Athens to do with Jerusalem? Is there happiness in the Torah? In B. A. Strawn (ed.), The Bible and the pursuit of happiness. New York, NY: Oxford University Press. McMahon, D. (2006). Happiness: A history. New York, NY: Atlantic Monthly Press, 77-81.

Mitchell, C. W. (1983). The meaning of BRK “To Bless" in the Old Testament. Atlanta, GA: Scholar's Press. National Council of the Churches of Christ. (1989). New Revised Standard Version Bible. Grand Rapids, MI: Zondervan.

Roberts, R. C. (2004). Gratitude: A conceptual analysis. In Robert A. Emmons and Michael E. McCullough (eds.), The psychology of gratitude. New York, NY: Oxford University Press, 77.

Rosenthal, E. I. J. (1971). The concept of Eudaimonia in medieval Islamic and Jewish philosophy. In E. I. J. Rosenthal, Studia Semitica, 2 vols. Cambridge: Cambridge University Press, 2:127-44.

Roth, N. (1981). "Attaining happiness (Eudaimonia) in medieval Jewish philosophy," Centerpoint 4 , 2132.

Seligman, M. (1991). Learned optimism. New York, NY: Knopf.

Tirosh-Samuelson, H. (2003). Happiness in premodern Judaism. New York: Hebrew Union College Press.

Voltaire. (1793/1901). Moses. (Philosophical Dictionary) In John Morley, The Works of Voltaire. A Contemporary Version. 21 vols. New York, NY: E.R. DuMont, 6: 41.

Walzer, M. (1985). Exodus and revolution. New York, NY: Basic Books. 